(DNA Amplification DAF استخدام مؤشرات بصمة الدنا المنضاعف

Oryza sativa L. في دراسة التنوع الور اثي للرز Fingerprint)

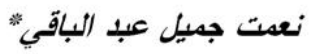

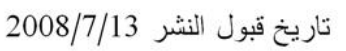

اجريت هذه الدر اسة لتحليل التتوع الور اثي لــ 10 اصناف من الرز الثائعة في العـــراق باســتخدام

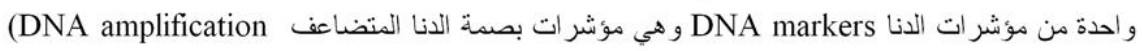
(fingerprint) (DAF)

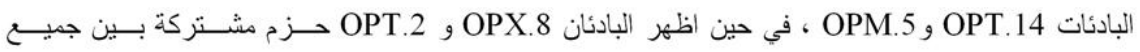

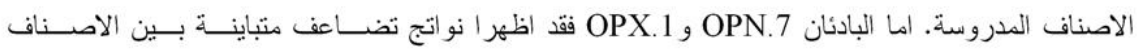

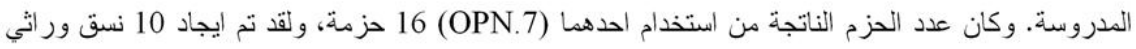

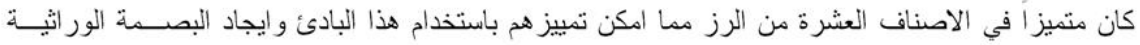

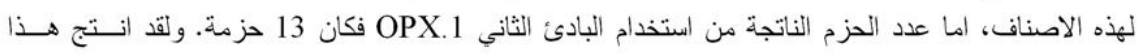

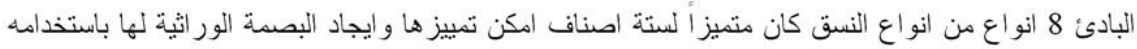

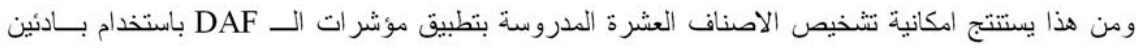

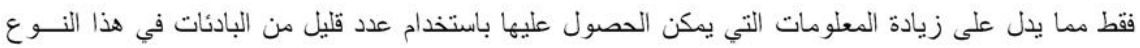

كلمات مفتاحية: بصمة الدنا المتضاعف، نتوع ور اثي، نسق ور اثي، مؤثرات الدنا.

عال من التتوع الحيوي ضروري جــأ للحفــاظ

يقصد بـالتتوع الــوراثي الاختلافـات

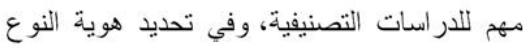

Populations الموجودة بين الافر اد او التجمعات التهردات

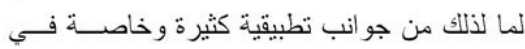

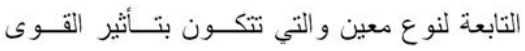
حفظ تلك الانواع وفي عمليات تتقية البذور وذلك الكي باستبعاد البذور التي لا تتطابق مع البذور الاصلية

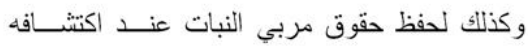

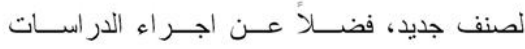

التطورية و البيئية عليها [3].

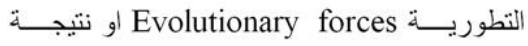

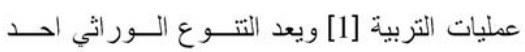

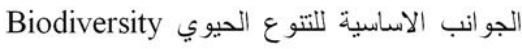
و التي تعني التتوع الموجود بين الانواع المختلفــة التحة

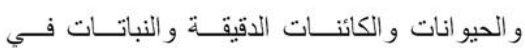
مجتمعاتها الطبيعية وان المحافظة على مسـتوى لكائ 
موقع ارتباط الباديء بالمجين [9]. وقد استخدمت

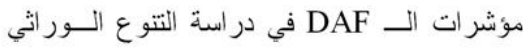

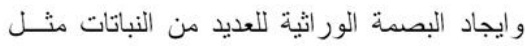

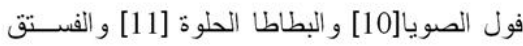

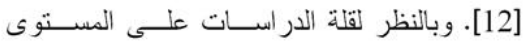
الجزيئي لنبات الرز و لاهمية هذا المحصول، لــذا لـات فقد جاءت هذه الار اسة للكثــف عـن التباينـات

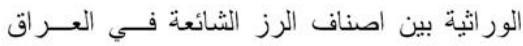

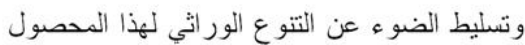

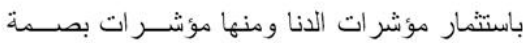

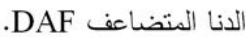

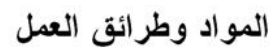

1- 1 - 1 - 1ضير النماذج:

تم الحصول على حبوب عشرة اصناف الفال

من الرز . Oryza sativa Lي العر اق وهي من مجمو عة (Indica group) وذللك مسـن محطـــة فئس ابحاث المحاصيل الحقليــة التابعــة الــى وزارة الزر اعة ومن تكنولوجيا البذور التابع الـى وزارة العلوم و التكنولوجيا وهي: عنبر محلــيـ- عنبــر ابيض - عنبر قصير - اباء 1 - اباء 2 - عنبــر

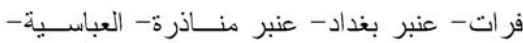

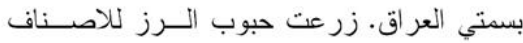

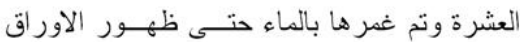
ل العزل الدنا منها.

2- 2 عزل وتوصيف الدنا:

تمت عملية عزل دنا اصناف الرز وفقــأ.

لطريقة [13] المعتدمة على طريقــة [14] و التــي لـي اعتمدت نفسها في عزل دنا اصناف الرز من قبل [15]. كما تم قياس تركيزه وتقدير نقاوته اســتناداً

الى [15] و [16].

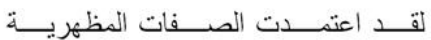

Morphological traits كمؤشر ات ور اثية Genetic markers للتمييـز

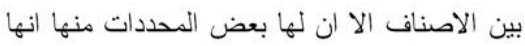

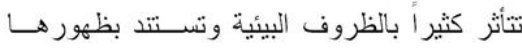

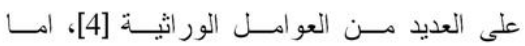

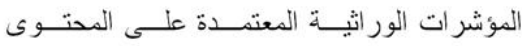
البروتيني و المتتــاظر ات الانزيميـــ Isozymes و التي استخدمت كطرق تمبزية وتصنيفية [5] فقد ولئ

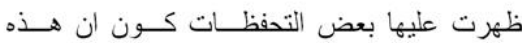

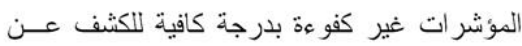
التباينات بشكل مستقر وشامل اضـــافة الــى قلــــة

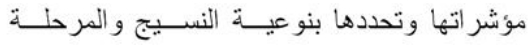

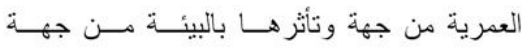

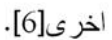

وبظهور مؤشرات الدنا DNA marker

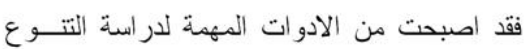

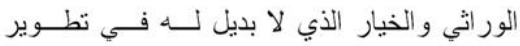

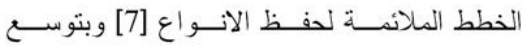

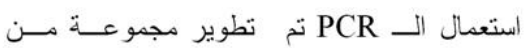
المؤشرات تستتد على التفاعل التضاعفي لسلســلة

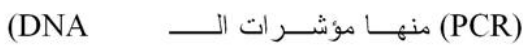
Amplification Fingerprint) DAF الدنا المتضاعف و المكتشفة من قبل [8] وهي احد

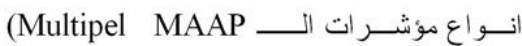
Amplification Amplicon Profiling) (النواتج المتضـاعفة المتعددة العشـــوائية) و التــي

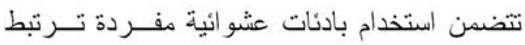
بالمو اقع المكملة لها على جانبي شريط الدنا ليــتم

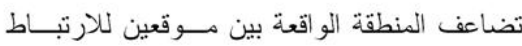

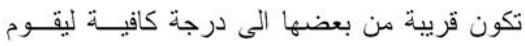

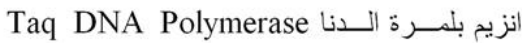
بعمله بالتضاعف، ويمكن الكثف عـن التباينـات بوجود او عدم وجود القطع المتضاعفة التي تظهر بلني على شكل حزم على الهلام و الناتجة مــن تغيــر 


\begin{tabular}{|c||c|}
\hline & رقم البادئ \\
\hline \hline OPD.14 & CTTCCCCAAG \\
\hline OPM.5 & GGGAACGTGT \\
\hline OPN.7 & GGGACCGGAG \\
\hline OPT.2 & GGAGAGACTC \\
\hline OPX.1 & CTGGGCACGA \\
\hline OPX.8 & CAGGGGTGGA \\
\hline
\end{tabular}

$$
\text { 4- بطوات العمل: }
$$

يتم اجر اء جميع الخطو ات تحــت هـــود

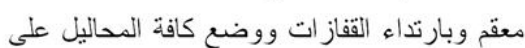

$$
\text { التظج. تتضمن خطو ات العمل ما يلي: }
$$

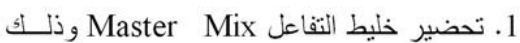

باضافة المكونات ادناه الى انبوبة معقمة حجم 1.5 مليلتر وكالاتي: باصني

$$
\text { 3- تحضير تفاعلات الــ DAF }
$$

تم استخدام الطريقة المعتمدة مسـن قبـلـل

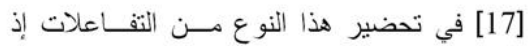

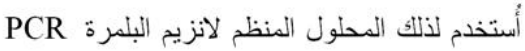

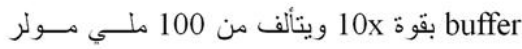
مــن التــرس الحامضــي Tris HCl ذو الاس من الهيدروجيني 8.3 و 50 ملي مولر مسـن كلوريســ

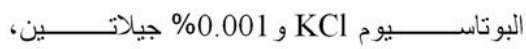
النيوكليوسيدات منقوصــة الاوكســجين الثنلاثيــة الفوسفات (dNTPs) وتشمل dGTP ، dTTP)

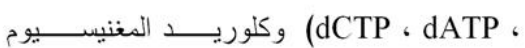

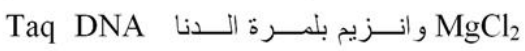
Polymerase ، زيت معدني اضافة الى جهـاز المبلمر الحراري الحلقي Thermocycler نــوع دعاني كما تم اختيار بادئات Primers hybrid

\begin{tabular}{|c|c|c|}
\hline التركيز النهائي & الحجم لعشر عينات & المكونات \\
\hline & 150 & ماء مقطر \\
\hline $1 \mathrm{x}$ & 25 & محلول منظم بقوة 10x \\
\hline 200 ملي مول & 25 & dNTPs \\
\hline 6 ملي مول & 10 & كلوريد المغنيسيوم \\
\hline 30 بيكومول & 30 & 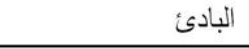 \\
\hline 2.5 وحدة & 2 & انزيم التضاعف \\
\hline
\end{tabular}
مجهزة من شركة Operon technologies هذه بـ

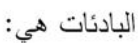

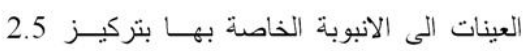

نانو غر ام/مايكروليتر ليصبح الحجــــ النهـائي لئي 25 مايكروليتر تمزج جيداً وتوضع بالمنبذة لعدة ثو اني لئي

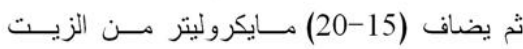

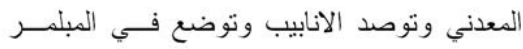
الحر اري الحلقي وفق البرنامج التنالي:

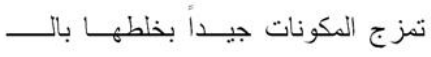

لمدة 30 ثانية ثم توضع في المنبذة لعدة

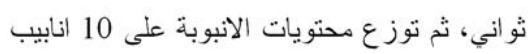

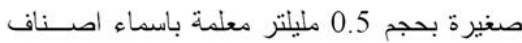

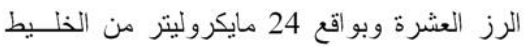

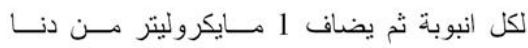


التحميل إلى 2.5 مايكروليتر من عينة دنا الــرز

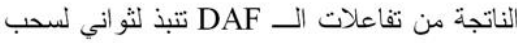
المكونات إلى أسفل الانبوبة. تفصل خيوط الــدنا المزدوجة وتحول إلى خيــوط مفــردة بو اســــة

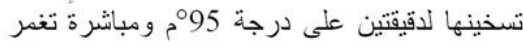

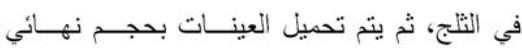

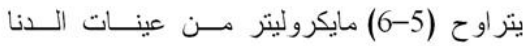
المتضخم ومحلول التحميل في الحفر ، وبعد انتهاء وقت الترحيل الذي بستغرق حو الي الساعتين بــتم

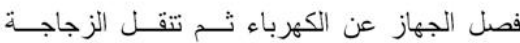

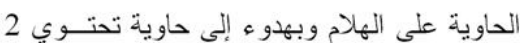
لتر من محلول الصبغة (نتر ات الفضة وتوضع على الهزاز لفترة ثلاثون دقيقة. بعسدها

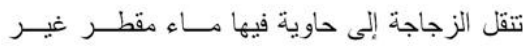

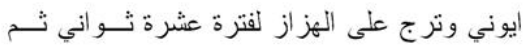
ترفع وتوضع مباشرة وبسر عة في محلول التظهير

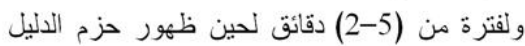

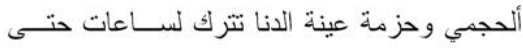

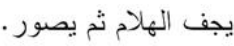

\section{النتائج و المناقشة}

تم عزل الدنا الكـــي لاصـــناف الـــرز

بكميات مناسبة وبمعدل يترو اح بـين 300-400

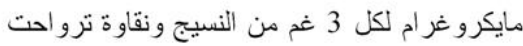

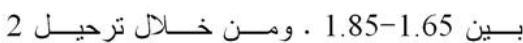

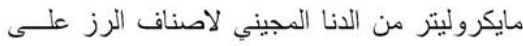

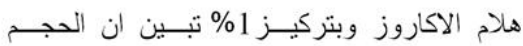
الجزيئي للانا كان بحدود $50 \mathrm{~Kb}$ بالمقارنة مع بنردين مايكروليتر من دنا العاثي لامبدا غير المهضـــوم بـون

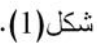

دورة واحدة بدرجة 94ْم لمــدة اربعـة

دقائق ثم 40 دورة كل دورة تتضمن: 920م لمدة

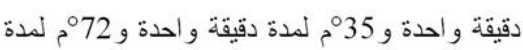

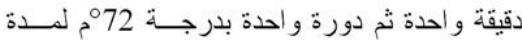

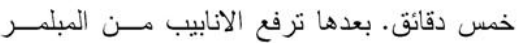

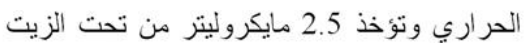

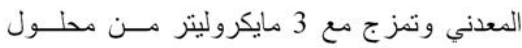

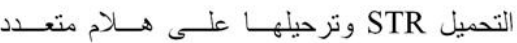

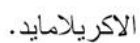

2. تحضـــير هــــام متعــــد الاكريلامايـــــ

Polyacrylamide Preparation

وفقـأ لمسـا وصــف فـي Technical

Promga الو ارد من الثركة المجهزة manual

. (DNA Silver staining system 1993)

حضر هلام متعدد الاكريلامايــد بتركيـز 6 \%

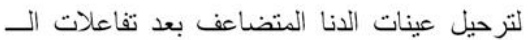

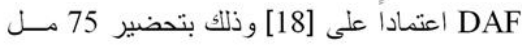
منه باستخدام المكونات التالية:يوريا يُوزن منها 31.5 غــم وبتركيـز

0.5x جيداً هذه المكونات و تذوب بشكل كامل ثم يصب

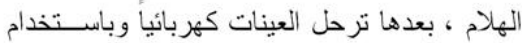

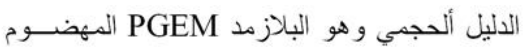

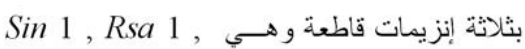
منتجة 15 قطعة معروفة الحجم الجزيئي وكالاتي: $36,45,65,75,126,179,222,350,396$, 460, 571, 676, 1198, 1605, 2645 قاعدي. يؤخذ منه 5 مايكروليتر ويضاف إلى 2.5

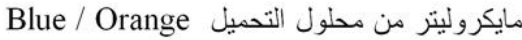

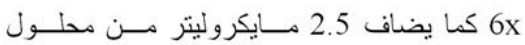




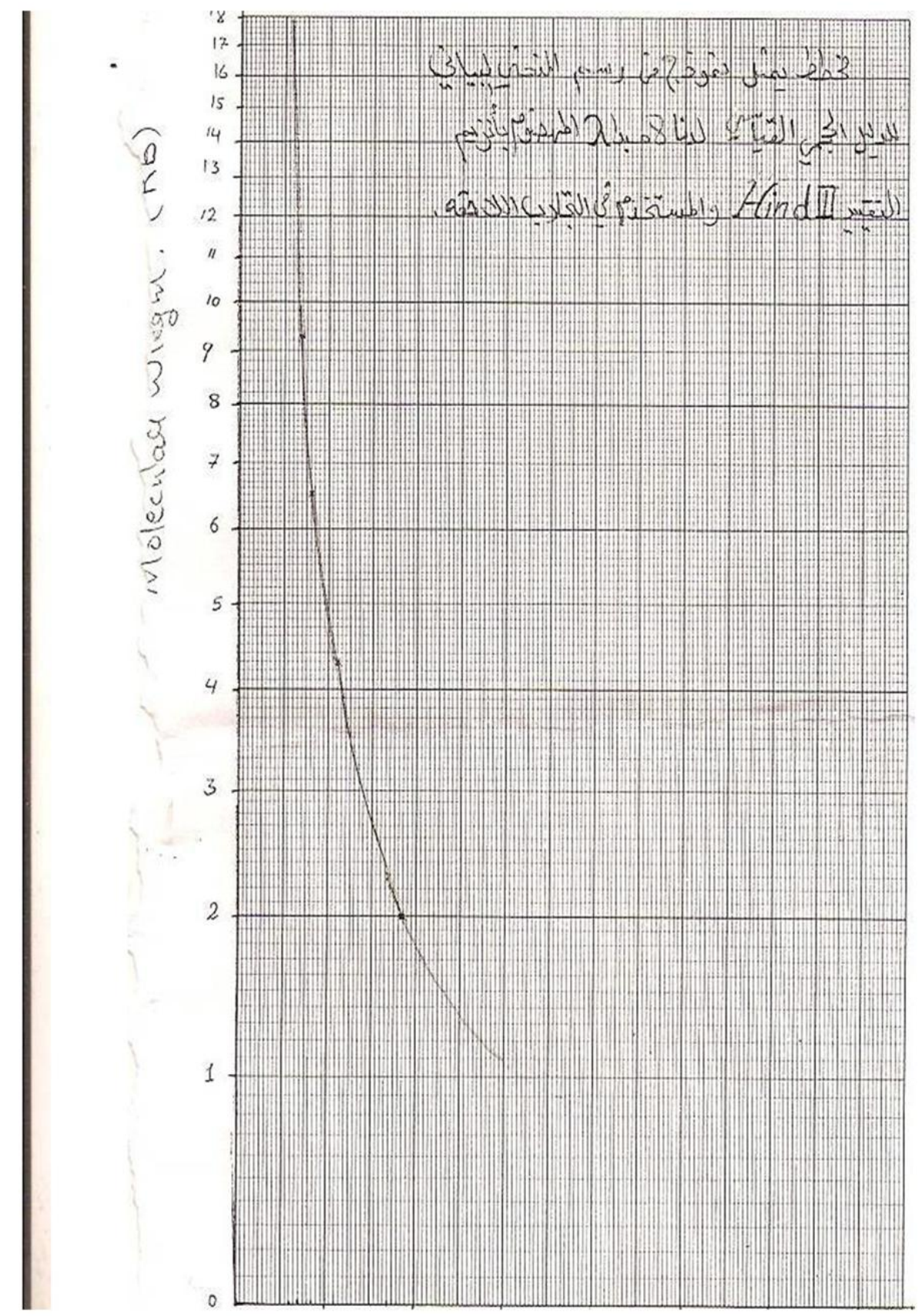

Distance $(\mathrm{cm})$ 


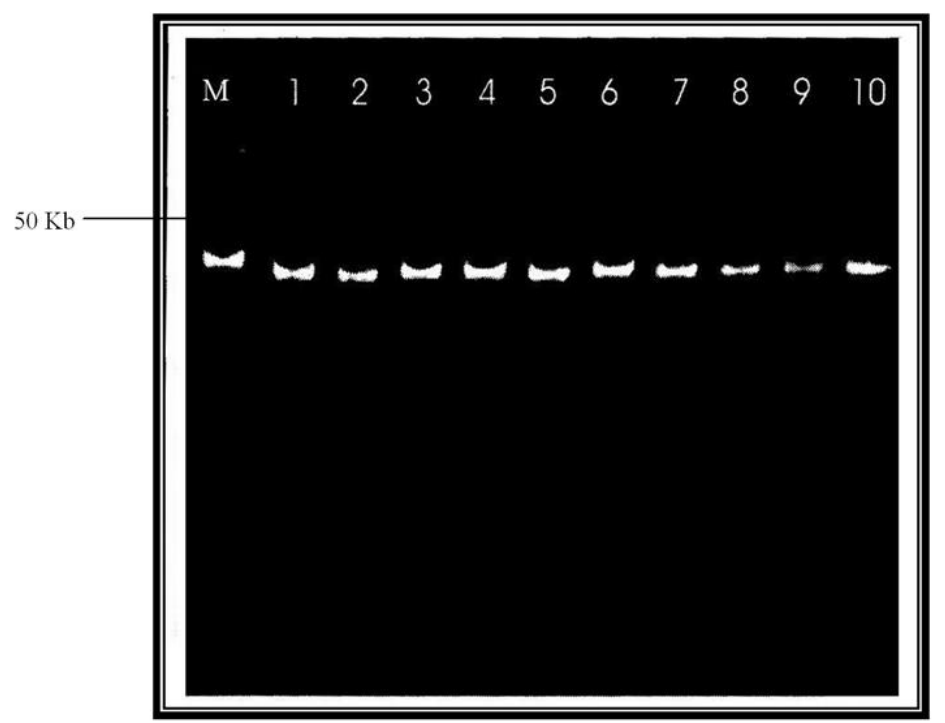

شكل (1): عينات الدنا المغزولة من اصناف الرز المدروسة والمرحلة على 1\% من هلام الاعسـاروز

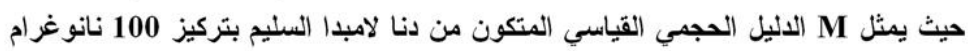
وتمثل الارقام تسنسل الاصناف كما يلي:

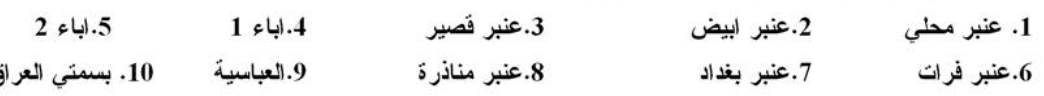

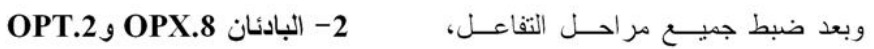

$$
\begin{aligned}
& \text { تم الحصول على حزم مثــتركة بــين } \\
& \text { اظهرت مؤشر ات الــ DAF نتائج مختلفة وفقــاً } \\
& \text { جميع العينات الــ } 10 \text { المستخدمة في هذه الدراسة } \\
& \text { للبادئات المستخدمة مع } 10 \text { اصناف من الرز وكما لـان } \\
& \text { باستخدام هذين البادئين شكل (2). و هذا يتفق مسع لـع } \\
& \text { [20] و اللذان وجدا بانه من مجموع } 359 \text { بـادئ }
\end{aligned}
$$

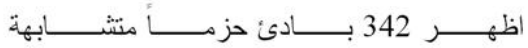

$$
\begin{aligned}
& \text { Monomorphic bands بين العينات المدروسة، }
\end{aligned}
$$

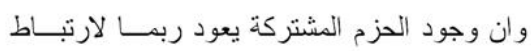

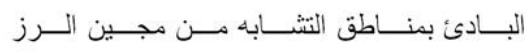

$$
\begin{aligned}
& \text { و لا يمكـن الاعتـــاد } \\
& \text { على هذه الحزم في ايجاد البصــمة الور اثيــة او لاوني }
\end{aligned}
$$

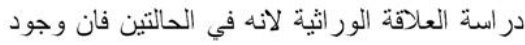

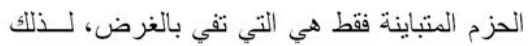

$$
\begin{aligned}
& \text { تم اهمال هذه النتائج و الاعتماد على نتائج البادئات } \\
& \text { التي اظهرت حزما متباينة فقط. }
\end{aligned}
$$




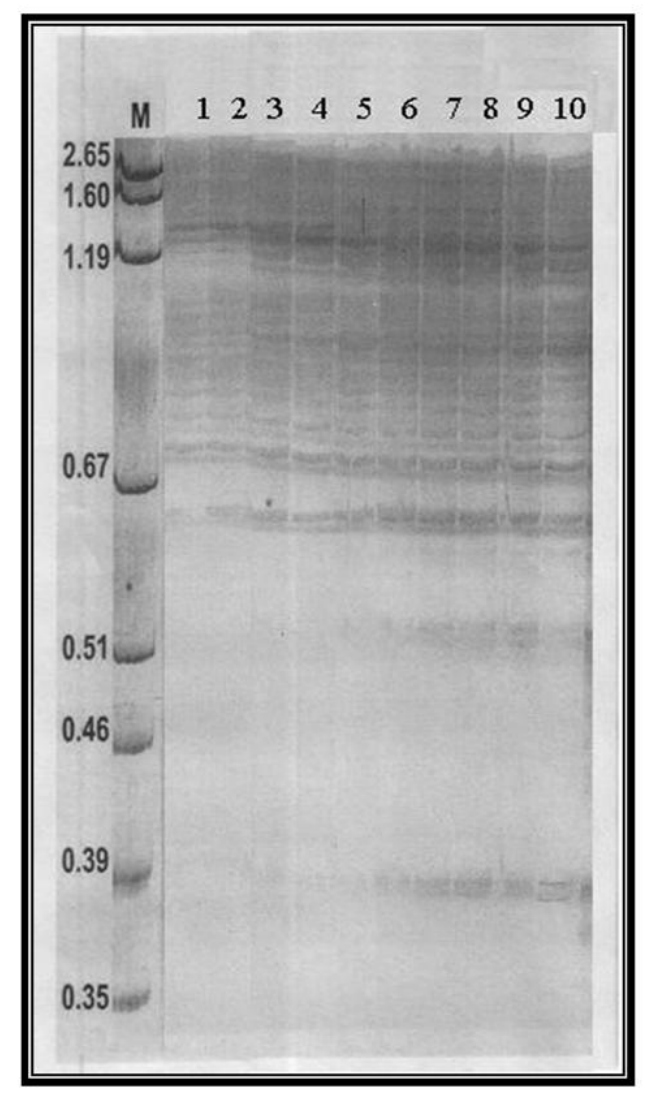

شكل (2): النواتج المتضاعفة من الدنا الكلي لاصناف المز المدروسة والمرحلة على هلام البولي اكريلامايد 6\% ب باستخام

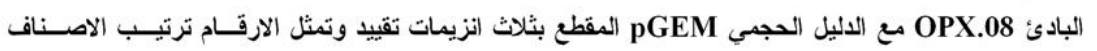

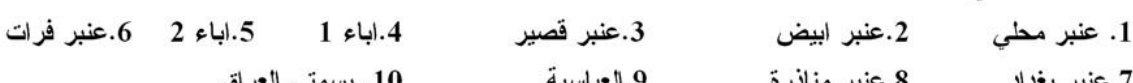

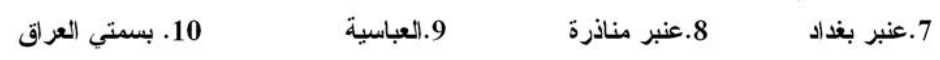

الدنا ذات الاوزان الجزيئية المتقاربة والتي تظهر

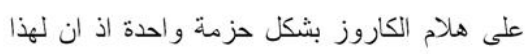

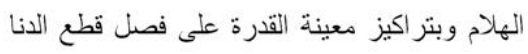

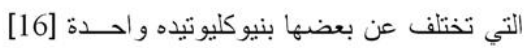

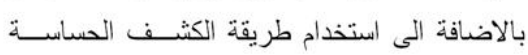

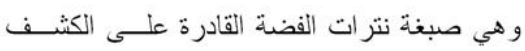

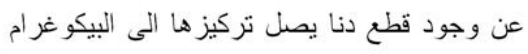

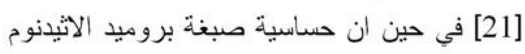

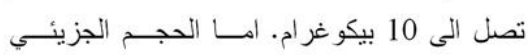

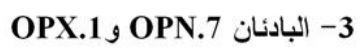

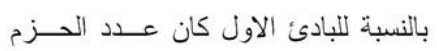

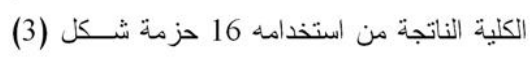
و هذا العدد يعادل ضعف معدل عدد الحزم الكليــة

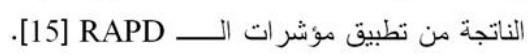
و هذا يعود وبشكل اساسي اضـافة الـى تغييــر

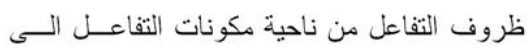

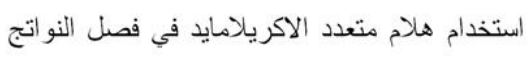

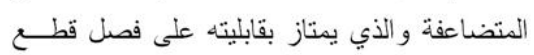




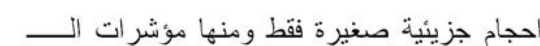

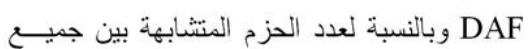
الاصناف فقد بلغ 4 حزم في حين بلغ عدد الحزم التي تباينت في ظهروها بين الاصناف 14 حزمة فئ

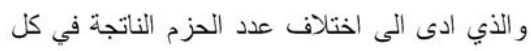
صنف و الذي ترواح بين 7 حزم في الصنف ابــاء الـاء 1 الى 16 حزمة في صنف العباسية مما ادى الى لى ايجاد 10 نسق ور اثي تميز هذا النسق في اصناف

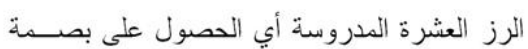

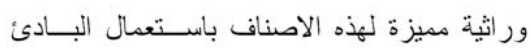

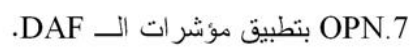

للقطع المتضاعفة باستخدام هذا البادئ فتر اوحست

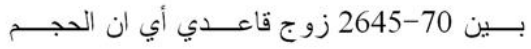
الجزيئي لاصغر قطعة متضاعفة كـان 70 زوج قاعدي في حين كان الحجم الجزيئي لاصغر قطعة لجني

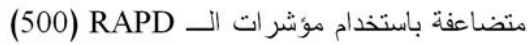
زوج قاعدي [15]، و هذه من مميـز ات اســتخدام هلام متعدد الاكريلامايد وهو قدرته على اظهــار

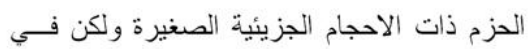

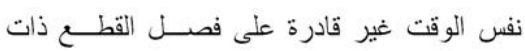

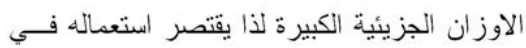

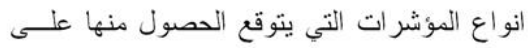

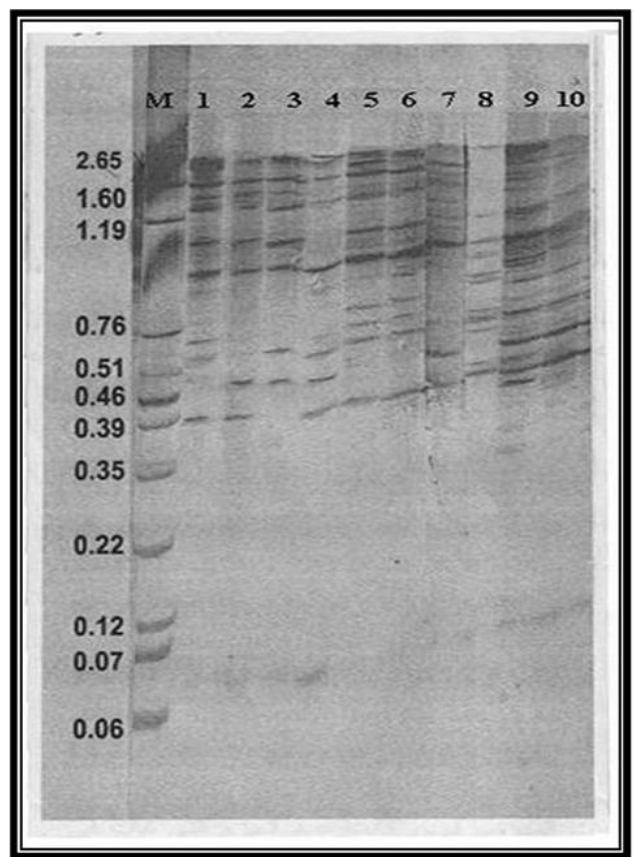

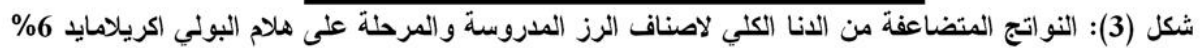

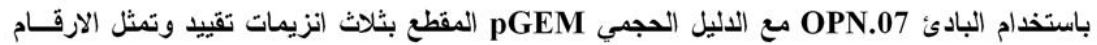

\begin{tabular}{|c|c|c|c|c|}
\hline \multirow[b]{2}{*}{ 5.باء 2} & \multirow[b]{2}{*}{ 4.اباء 1} & \multirow[b]{2}{*}{ 3.عنبر قصبر } & \multicolumn{2}{|c|}{ ترتيب الاصناف كالاتي: } \\
\hline & & & 2.عنبر ابيض & 1. عنبر محلي \\
\hline 10. بسمتي العراق & 9.العباسية & 8.عنبر مناذرة & 7.عنبر بغداد & 6.عنبر فرات \\
\hline
\end{tabular}

عدد الحزم الناتجة من استخدام كــل بـادئ مــن

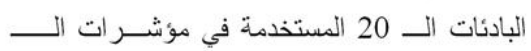

[15] RAPD، تراوحت الاحجام الجزيئية للقطع

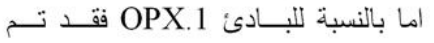

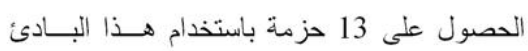

$$
\begin{aligned}
& \text { شكل (4). وهذا العدد من الحزم كان اعلى مــن بـن هـن }
\end{aligned}
$$


كان هذا النسق متمبز أ في 6 اصناف مسـن الــرز و الذي يعني ايجاد بصمة ور اثية لها باستخدام هذا

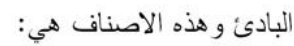
عنبر محلي، اباء 1، اباء 2، عنبر فرات، عنداء عنبـر

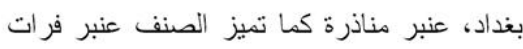
بوجود حزمة ذات وزن جزيئي 2558 كيلو زو جني قاعدي ظهرت في هذا الصنف فقـ دون دون بقيــة

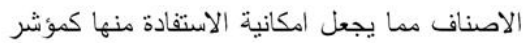
خـاص بالصــن Cultivar specific marker الاصنـ ويمكن استرجاع الحزمة مــن الهــام وكلونتهـ

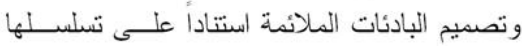
لتكون بمثابة مجس مرتبط بهذا الصنف خاصة اذا لهات عرفنا بان استرجاع حزمة من هلام الاككريلامايد

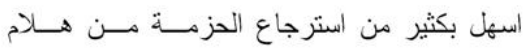
الاكاروز وذلك لاختصار خطوة النتقية فيها.
المتضاعفة بين (420-2650) كليو زوج قاعدي اما عدد الحزم الناتجة من استخدام هذا البادئ مع رع جع

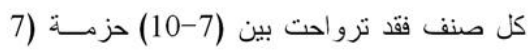
حزم في الاصناف: اباء1 و عنبر فــرات و عنبـر

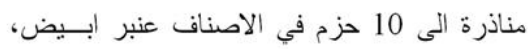
عنبر قصير عنبر بغداد). وهذا الاختلاف ناتج من الاصن اختلاف عدد المواقع المكملة لتسلسل البادئ فـي ني تلك الاصناف و الناتجة من الاختلاف فـي المــادة

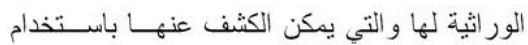

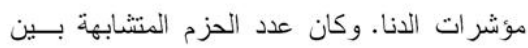

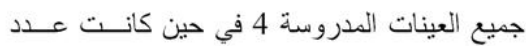
الحزم التي تباينت من ظهور ها بين الاصـــناف 9

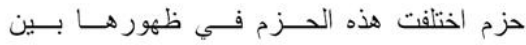
الاصناف مما ادى بدوره الى ايجاد عدة انواع من فن فئ

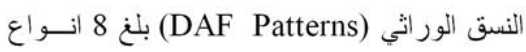

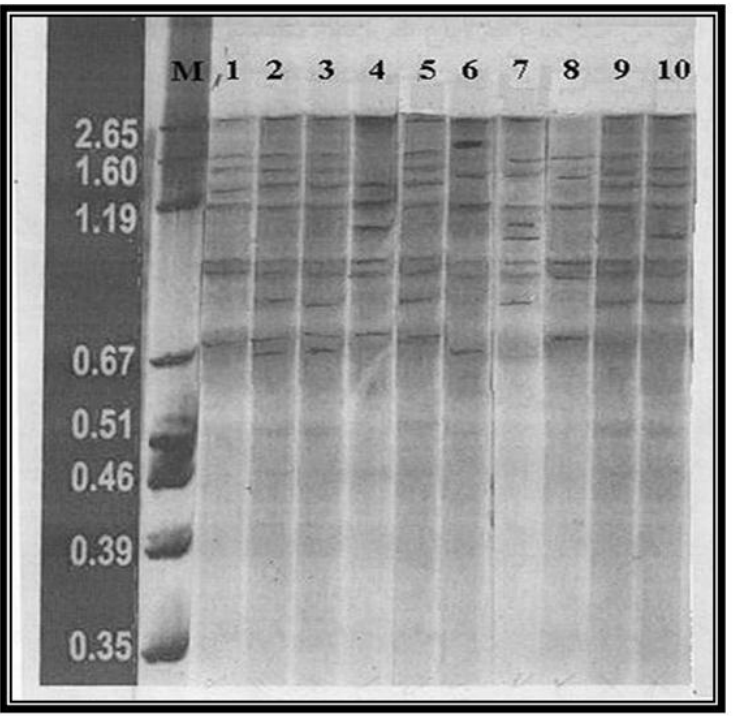

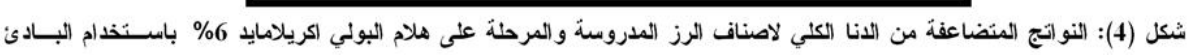

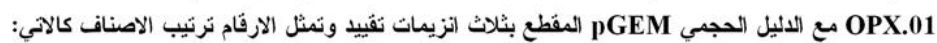

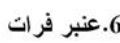

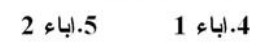
3. 3نبر قُصير

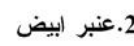

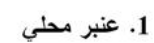

$$
\text { 10. بسمني العراق } 10
$$

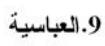

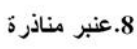

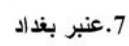

تجربة 6 بادئات، و هذه النتيجة مشجعة للاستمر ار

ومن هذا نستتنج بانه امكن ايجاد بصمة

في هذا النوع من المؤشر ات في در اسات مقبلــــة

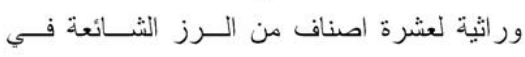

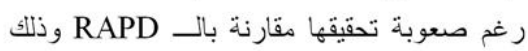

العر اق المدروسة باستخدام بادئين فقط وبعد لـنز 
in plant improvement. Adv. Agron.46:39-90.

8. Caetano-Anolles, G., Bassam, B.J. and Gresshoff, P.M. 1991, DNA amplification fingerprinting using very short arbitrary oligonucleotide primers. Biotechnology. 9:553-557.

9. Wilde, J. Waugh, R. and Powell, W. 1992, Genetic fingerprinting of Theobroma clones using randomly amplified polymorphic DNA markers. Theor. Appl. Genet. 83:871-877.

10. Caetano-Anolles, G. and Gresshoff, P.M. 1996, A method for profiling nucleic acid of unknown sequence using arbitrary oligonucleotide primers US. Patent. 5:413-414.

11. Jarret, R.L. and Austin, D.F. 1994 , Genetic diversity and systematic relationship in sweet potato (Ipomoea batatas) and related species as revealed by RAPD analysis. Genet. Res. Crop. Evol.41:165-173

12. He, G., Prakash, C.S. and Jarret, R.L. 1997, Analysis of genetic diversity in sweet potato (Ipomoea batatas) germplasm collection using DNA amplification fingerprinting. Genome. 38:938945.

13. Weigand, F., Baum, M. and Udupa, S. 1993, DNA molecular marker techniques. Technical manual. No.20 International Center for Agricultural Research in the Dry Areas, Aleppo, Syria.

14. Sahgi-Maroof, M.A., Soliman, K.M., Jorgens, R.A. and Allard, R.W. 1984, Ribosomal DNA spacer length polymorphisms in barley, Proc. Natl. Acad. Sci. USA. 81:8014-8018.

15. Al-Judy, N.J. 2004, Detecting of DNA fingerprints and genetic relationship analysis in local and Improved Rice (Oryza sativa L.) varieties in Iraq using RAPD
لزيادة المعلومات التي يمكن الحصول عليها مسن

استعمال عدد قليل من البادئات وخاصة اذا كـــان

هدف تللك الدراسات ايجاد البصمة الور اثية الــذي لـئي

يفضل استخدام المؤشر الذي يحوي على عدد اكبر

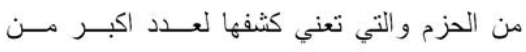

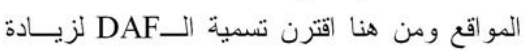

استعمالك في مجال البصمة الور اثية.

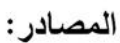

1. Karp, A., Edwards, K.J., Buford, M., Funk. S., Vosman, B., Morgante, M. and Hewitt, G.M. 1997, Molecular technologies for biodiversity evaluation: opportunities and techniquies. Nature Biotechnology. 15:625-628.

2. Tilman, D., Wedin, D. and Knopps, J. 1996, Productivity and sustainability influenced by biodiversity in grassland ecosystems. Nature.379:718-720.

3. Karp, A. and Edwards, K.J. 1997 , DNA Markers: a global overview, In: Caetano-Anolles, G. and Gresshoff, P.M. (Eds) DNA markers, Protocols, Application and Overview. Now York.:1-13.

4. Staub, J.E., Serquen, F.C. and Gupta, M. 1997, Genetic markers, map construction and their application in plant breeding. Hort. Sci. 31:729-741.

5. Stuber, C.W. and Khanna, K.R. 1991, Isozyme markers and their significance in crop improvement. Biochemical aspects of crop improvement. CRC Press, Boca Raton, USA.:59-77.

6. Kraic, J., Horvath, L., Gregova, E. and Zak, I. 1995, Standard methods for electrophoretic separation of wheat glutenins and gliadins by SDS-PAGE. Rostl Vyr. 41:219223.

7. Paterson, A.H., Tanksly, S.D. and Sorrell, M.E. 2004, DNA Markers 
19. Trigiano, R., Caetano-Anolles, G., Bassam, B.J., Weaver, K.R. and Gresshoff, P.M. 2002, DNA amplification fingerprinting of doywood anthracnose Fungi Proc. South. Nurs. Assn. 15:10-17.

20. He, G. and Prakash, C.S. 1997, Identification of polymorphic DNA markers in cultivated peanut (Arachis hypogaea L.) Euphytica,. 97:143-149

21. Bassam, B.J., Caetano-Anolles, G. and Gresshoff, P.M. 1992, DNA amplification fingerprinting of bacteria. Appl. Microbiol. Biotech. 38:70-76. markers. Ph.D. a thesis. Baghdad University. College of Science.

16. Sambrook, J., Fritsch, E.F. and Maniatis, T. 1989, Molecular cloning: a laboratory manual. 2nd. Cold spring Harbor. N.Y.

17. Caetano-Arolles, G., Bassam, B.J. and Gresshoff, P.M. 1994, DNA amplification fingerprinting with very short primers. Plant Mol. Biol. Rep. 19:18-25

18. Bassam, B.J., Caetano-Arolles, G. and Gresshoff, P.M. 1991, Fast and Sensitive silver staining of DNA in polyacrylamide gels. Anal. Biochem. 38:70-76.

\title{
Use of DAF markers (DNA Amplification Fingerprint) to Assess Genetic Diversity of Rice (Oryza satival L.)
}

\author{
Neamat J. Al-Judy* \\ * Biology Dept. - College of Science - Baghdad university
}

Key Words: DNA Amplification Fingerprint, genetic diversity, genetic pattern, DNA Markers

\begin{abstract}
This study was carried out to assess genetic diversity of ten cultivars of Rice (Oryza sativa L.). One of DNA markers based on Polymerase Chain Reaction (PCR) was used namely DAF markers (DNA Amplification Fingerprint). Six primers were tested, the results showed, that no amplification products using the primers OPD.14 and OPM.5. Two primers (OPX.8 and OPT.2) produced monomorphic band across all cultivars, while only two primers generated polymorphic bands. The number of total bands produced from one of them (OPN.7) were sixteen. Also this primer produced ten polymorphic profiles (DAF patterns) which were unique to the ten cultivars that could be distinguished. The number of total bands generated by primer OPX.1 were thirteen and this primer produced eight polymorphic patterns which was unique for distinguishing six cultivars. This means that DAF markers were able to identify all rice cultivars using only two primers reflecting the high potentialities of these markers for their applications in fingerprinting.
\end{abstract}

